\title{
Meta-Action Research on a Leadership Development Program: A Process Model for Life-long Learning
}

\author{
Margaret A Fletcher ${ }^{1}$, Ortrun Zuber-Skerritt ${ }^{2}$, Brendan Bartlett ${ }^{3}$, \\ Ruth Albertyn ${ }^{4}$ and Judith Kearney ${ }^{5}$
}

\section{Contact address:}

Dr Margaret A Fletcher

Griffith Institute for Educational Research

Griffith University

176 Messines Ridge Road

MT GRAVATT QLD 4122, Australia

Phone +61 737356869

Fax +61 737355965

Emailm.fletcher@griffith.edu.au

\footnotetext{
${ }^{1}$ Senior Lecturer, Faculty of Education, Griffith University, Brisbane, Australia

${ }^{2}$ Adjunct Professor, Faculty of Education, Griffith University, Australia, and

Professor Extraordinaire, Tshwane University of Technology, Pretoria, South Africa

${ }^{3}$ Professor, Faculty of Education, Griffith University, Australia

${ }^{4}$ Researcher and consultant, Centre for Higher and Adult Education, Stellenbosch University, South Africa

${ }^{5}$ Lecturer, Faculty of Education, Griffith University, Australia
} 


\title{
Meta-Action Research on a Leadership Development Program: A Process Model for Life-long Learning
}

\author{
Margaret A. Fletcher, Ortrun Zuber-Skerritt, Ruth Albertyn, \\ Brendan Bartlett and Judith Kearney
}

\begin{abstract}
Our purpose in this paper is to contribute to the field of systemic practice by sharing a process of professional learning based on meta-action research. The process emerged as we engaged with evaluation data from a leadership development program (LDP). The aim of this LDP had been to help leaders design their team projects on poverty reduction through action research methods in six African countries. As facilitators of the program we discuss our experiential learning based on critical reflection. We explain how meta-action research can transform understandings of ways to improve professional practice in future applications. We present three process models: (1) a model of reflection on action, (2) a meta-action research model, and (3) a model for lifelong learning through meta-action research. These models may be of benefit and interest to readers who facilitate systemic practice and action research in education, higher education, communities, industry and government.
\end{abstract}

Keywords: Systemic practice, meta-action research, reflective practice, lifelong learning, leadership development.

\section{Introduction}

This paper is a sequel to an article published in this journal (Fletcher and ZuberSkerritt 2008). In that article we reflected on three case studies on action research (AR) for professional development (PD) in South African higher education and presented five models: (1) the AR workshop cycles; (2) characteristics of a quality PD program; (3) a PD program on and through AR; (4) three levels of reflection on AR; and (5) meta-action research.

In the present paper we reflect on a leadership development program (LDP) with participants from six African countries whose aim was poverty reduction through action learning and action research. Our participation in this LDP program provided the stimulus and context for us to develop a deeper understanding of the role critical reflection plays in lifelong learning and transformation of systemic practices. Therefore, the focus of this paper is not an evaluation of the LDP beyond the workshop itself, but a critical evaluation of ourselves and the roles we played throughout the program. 
Our purpose in engaging in this process was to gain deeper understandings about ourselves and to improve the work we do as action researchers. While the LDP generally was highly evaluated by the participants, the authors, as the leadership team, were left with a sense of unfinished business. Questions about how effectively the progam had prepared participants to complete their projects remained. As we reflected on these concerns and discussed ways we could learn from this, we decided to document our thinking and learning in an effort to capture the lived experiences we shared as we reflected and learnt from each other.

We describe a multi-phase process designed to explicate how, as members of a community of learners, we expanded our interpretation of events beyond literal and superficial understandings of shared experience through shared reflection on that experience.

Reflection - thinking carefully about the past, present and future - is usually understood as a solitary, high level thinking activity, and much in the literature reports on its effectiveness as an internal, individually-situated cognitive process (Boud, Keogh and Walker 1985, Joseph 2003). However, like Schön (1987) we recognize a need to reconceptualize reflection as a lived experience explored through others. Reaching beyond one's own mind, reflection is also pursued productively through the minds of others. It is made explicit through conversations or other forms of dialogue, through questions, answers, models and wonderings that these exchanges provoke, and the linkages, challenges, resolutions and continuations they inspire.

Social engagements often engender contexts appropriate for valuable change and learning (Bartlett and Elliott 2008). Opportunities to engage with minds that think differently from our own open windows for actively and developmentally transforming our practice. Such development is characterized by greater levels of abstraction and de-contextualization rather than the mere specifics of human practice (Guile and Griffiths 2001). It is what the mind does with the learning, expanding our ability to generate new ideas, and apply these creatively to promote and enable transformation. In this paper we document our understanding of this developmental process and propose new process models that can be used when designing, conducting and evaluating programs for developing leadership and change. Our experience in preparing this paper illustrates how, through reflective collaboration with each other as co-authors, we came to think and understand more expansively with the mutual stimulation of others' minds as mirrors to our own. Meta-reflection - our iterative shared reflections on our individual reflections - developed the minds of all of us as we developed ways to improve our work in facilitating leadership development programs through action research.

Action research has been defined from many different perspectives, as can be seen in the three editions of the Handbook on Action Research by Reason and Bradbury (2001, 2006, 2008), the literature reviews by Dick (2004, 2006, in press) and other recent works (Greenwood and Levin 2007, Stringer 2007, Altrichter et al. 2008, Berg and Eikland 2008, McIntyre 2008, Gray 2009, McNiff and Whitehead 2009) but there is general agreement that it is a methodology for change and development (ZuberSkerritt, 1991, Somekh 2006, Somekh and Zeichner 2009). However, action research - like qualitative research in general - is criticized often from conservative 
governments and academics (Denzin 2009), although it is recognized as an appropriate and effective methodology for professional and leadership development, especially in developing countries (Louw and Zuber-Skerritt 2009, Zuber-Skerritt 2007a, 2007b, 2009).

From its very beginning (Lewin 1948, 1952) to the present time, authors have agreed that action research integrates research (inquiry) and action (development) through a cyclical, collaborative process of planning, acting (implementing the plan), observing (and evaluating the action) and reflecting on the results of the evaluation and on the learning that takes place for all participants in the research (Kemmis and McTaggart 1988, and 2010 as foreshadowed by Kemmis 2009).

We begin with explanations of reflection and meta-reflection as learning, and a definition of meta-action research as the key notions used in our modelling. We explain the process of meta-action research on our leadership development program (LDP) under the headings of pre-action reflection on the design of the LDP; in-action reflection on implementing the LDP; post-action reflection on the results of the LDP and our transformational learning; and pro-action reflection on improving our practice in future programs. We aim to contribute to knowledge in the field of meta-action research by conceptualizing the processes of our reflective practice in three new models: (1) a model of reflection on action, (2) a meta-action research model, and (3) a model for lifelong learning through meta-action research.

\section{Reflection and Meta-Reflection}

The role of reflection in lifelong, systemic, transformative learning is reported extensively. Mezirow (1978, 1991) is credited with coining the term 'perspective transformation' to identify a process now better understood as transformative learning. Critical reflection is recognized as an essential part of this process. However, critical reflection on one's own practice can be confronting and difficult. For many it is a developmental process where learners revert to a comfort position to describe rather than analyse, explain or account for the learning and to identify what contributed to it (Fletcher 2005). As Gustafson and Bennett (1999) found when promoting reflection with military cadets, factors related to the learner, the environment and the reflection task influenced the cadets' reflective behaviour. For us, environmental characteristics, particularly those that promote interpersonal interaction, resonated with our participatory approach. We see these as important to collaboratively develop ourselves as reflective action researchers and to transform our practices in ways that benefit the people with whom we work and engage in our communities. Zemblyas (2006) and Procee (2006) have noted limitations of the reflection process if conducted uncritically. Procee (2006: 241) states that reflection 'takes a critical stance toward the (repressive) actual situation, thus opening up a horizon of liberation'. We wanted to reach for that horizon by consciously fleeing our comfort zones and resisting simple description, on the understanding that description without critical thought limits capacity to 'grow' insight and self-awareness.

Having learned, learners may take an additional cognitive step in critically reflecting on and analysing what shaped and influenced their learning. They may be consciously aware of both the processes they are using and their own strategic 
capacity to apply these and alternative processes differently and better. This additional sequence is learning about learning and accounts for the why, how and when conditions that typically enhance the what aspect of learning (Bartlett and Elliott 2008). Reflecting on our own learning process incorporates an evaluative element that offers insight about self as the primary agent of the process; it grounds transformation for future learning and action.

Reflecting at this meta level is a higher-order cognitive task that has a reflecting-onreflection dimension, with our contention that reflecting on others' reflections as well as our own is an important enactment of meta-action research. It may bring others to recognize that what they thought they 'know' is the product of their own and others' biases, affiliations, proximity and subjectivity. In this more advanced state of 'understanding', they may recognize or 'know' that there are different understandings of knowledge and that they may not 'know' anything at all. Meta-thought/reflection may therefore enable us to come to terms with subjectivity in the production of knowledge. Such is the grand turf of epistemology. An alternative view could suggest that reflecting at a meta level opens us to self-delusion, perhaps due to one's biases or affiliations or proximity to an event.

Working in a professional learning community has the potential to moderate these risks through collective reflection, where members respond to each other's interpretation of an event and offer alternative perspectives and accounts through critical conversations about elements of reasoning (Hatton and Smith 1995). If one sees outcome of meta-thought/reflection as fruitful and positive (from new cognisance of 'knowledge') rather than as risk, collective reflection can advantageously bring others to this cognisance, and enable members to develop new understandings as they respond to each other's interpretations. Ottmann, et al. (2009) suggest iterative operational and methodological 'reflection rounds' offer opportunities for all stakeholders to participate in this process.

Procee (2006) discussed a Kantian epistemology of reflection in education and suggested two dimensions of reflection: understanding, related to the ability to grasp logical, theoretical and conceptual rules; and judgement, related to the ability to connect experience with rules. To engage in reflection at this level requires time, commitment and expertise.

In furthering our understanding of meta-action research through applying critical, reflective processes, we observed that while there is considerable literature on this topic, the documenting of actions taken by individuals and the processes that they have engaged in are often limited or written from a more objective, etic perspective. In this paper we consciously record our efforts to reflect at a meta-action research level and describe the experiences that underpinned the processes. These processes align with the work of Zimmer (2001) who described the "I", "you" and "we' reflective process in an interpersonal action-learning cycle which consciously progresses an individual's interpretation of an event to a shared understanding that is explicit in its reflexivity. This "unfolding” as described by Churchman (1979) and applied by Reynolds (1998) as a dialectical process enabled us to critically reflect on our actual work within an evaluative framework which focussed on understanding our roles as "we". 
Our narrative describes the story of how we engaged in iterative conversations that provided learning opportunities for the authors to collectively improve our practice as we moved from introspectively examining the "actual" to work towards an "ideal" (Reynolds, 2008). These conversations formed the basis for meta-reflection in metaaction research through the course of our collaborative involvement in a leadership development program (LDP) for community leaders in six African countries. It is beyond the scope of this paper to discuss this LDP in detail, but we have summarized its main topics, issues and approach in Appendix 1.

Our experiences are documented and evaluated through a process of cycles in a spiral of meta-action research. Later in this paper we attempt to describe the discursive experiences that we believe led to deeper understandings about ourselves, our work and those with whom we worked in the LDP. The socio-cultural context of the program held in South Africa and its participants from other parts of Africa is very different from our experience of everyday life in Brisbane. We believe this difference heightened our sensitivity and thus our own learning and meta-learning experiences.

\section{Meta-Action Research}

Our interpretation of the term "meta-action research" is evolving as we develop our understandings of how to learn through critical reflection that involves a multi-level, interpersonal, dialectical approach to understanding and learning from our experiences.

Zuber-Skerritt (1992) defined the term meta-action research to mean 'action research on action research' and 'research and reflection on action research' (1996). Since then, Trevitt (2005) cited and adopted this term, comparing 'meta-action research' to 'second-order action research'. More recently, Fletcher and Zuber-Skerritt (2008: 76) explained:

Meta-action research is beyond the action research activities and processes. It is the highest level of conceptualizing, abstracting and generalizing the action research results through self-critical reflection-that is, it is action research on action research.

We have now re-conceptualized meta-action research in the following definition:

Meta-action research is action research on or about action research. It is based on reflection, self-reflection, conceptualization and theorization of the activities, processes, methods and results of the action research program(s) or project(s), denoting systemic change, transformation, awareness and understanding of one's own learning, and arriving at higher-order concepts, principles, theories or models of action research.

We build on Flood's view of a nexus between systemic thinking and action research (2001: 142-143):

It is through systemic thinking that we know of the unknowable. It is with action research that we learn and may act more meaningfully within the 
unknowable. Where these two arcs of reasoning converge, we witness the incredible genesis of a conceptual universe that opens up otherwise unimaginable ways in which people may live their lives in a more meaningful and fulfilling manner. ... However, systemic thinking is not an approach to action research, but it is a grounding for action research that may broaden action and deepen research.

This paper illustrates how such systemic thinking within a meta-action research model also transforms the researcher(s).

\section{The Process of Meta-Action Research: Reflection on Pre-, In-, Post- and Pro-Action (PIPP)}

The following section describes the processes in which we engaged as we embedded 'reflection on action' - a term first used by Schön (1983) - in each phase of our involvement in the project described in the following section. Each phase constitutes a cycle in the spiral of action research as shown in our model in Figure 1. We have named this model PIPP after its acronym for the Latin pre-fixes we used: pre-, in-, post-, and pro (before, during, after and for) action. A more detailed description of the model will follow in section 2.4 (cycle 4). ${ }^{6}$

Take in Figure 1 about here

\section{Pre-Action Reflection: Reflection on the Planning Phase (Cycle 1)}

The first phase of this process focused on our reflections during the preparatory work of planning. Through collaboration with South African colleagues on other projects, we had come to recognize the potential utility of an action research based leadership development program (LDP) to develop leadership among community leaders from elsewhere in Africa. Our meetings were action oriented. We collaboratively planned and reflected on what we wanted to achieve and potentially could achieve through the LDP, how it could be delivered and how we could obtain funding for it. We designed a program to meet the criteria for the International Seminar Support Scheme (ISSS) funded by AusAID, Australia's official foreign aid program. This was a decontextualized process based on our previous experiences in writing grant applications and facilitating workshops on action research.

Brainstorming, mind-mapping and revisiting past experiences underpinned our application for funding and our design of the 'seminar' as a three-day workshop in the LDP. We contacted our South African colleagues to outline our initial intentions, and creatively anticipated, imagined, predicted, produced and collaborated as an international team about ways the workshop might develop. The focus of this first cycle was theoretical. We drew on our experiences of past workshops in developing countries and imagined possibilities for future programs. While we were confident in applying for grants and writing leadership programs, we were ignorant about our future participants from six African countries. Who would they be? What would be

\footnotetext{
${ }^{6}$ This PIPP model is not the same as the PIP model representing the acronym for Preamble - Interview - Postscript, as developed in Zuber-Skerritt (2009).
} 
their experiences, abilities, needs and expectations? How might we help through the LDP? To find out, we conducted a target analysis.

The first action research cycle consisted of (1) planning the LDP; (2) taking action, i.e. writing the draft proposal; (3) observing, i.e. seeking feedback from critical friends and stakeholders; and (4) reflecting on the feedback and our own selfevaluation.

Outcomes at the end of this phase were a completed grant application ready for submission to AusAid and a leadership development program designed to assist colleagues from African countries by using action research as a framework for their consideration in strengthening and implementing poverty-reduction projects.

On being informed that the grant application was successful, selection criteria were used to choose the 21 program participants. These criteria warrant explanation since they influenced the group dynamics of the program. Proposals from six African countries were submitted in the grant application and three of these proposals (from Kenya, Tanzania and Uganda) (12 delegates) were accepted, based on AusAID's criteria for selection. Three delegates received funding from Stellenbosch University in South Africa and six others were self-funded. A week before the workshop a target analysis survey was conducted where participants were invited to identify topics they wanted to explore (see Table 1). They were asked also to provide an outline of their projects. Three participants did not return the target analysis.

Take in Table 1 about here

Project themes for the three AusAID-funded teams from Kenya, Tanzania and Uganda respectively, focused on:

- poverty reduction, improved health and environmental management;

- women's participation and empowerment in community conservation; and

- professional education in health.

Foci of the non-AusAID delegates' projects included mentoring in higher education (Malawi); professional development in higher education (Mozambique); and HIV prevention; improving primary health care; and, moral transformation through ethical leadership (South Africa).

\section{In-action Reflection: Reflection on the Implementation Phase (Cycle 2)}

Throughout this three-day workshop we applied an action learning model to formatively evaluate the program (see Fletcher and Zuber-Skerritt 2008) and to ensure we were meeting participants' needs. Evaluation data allowed us to adapt sessions when possible, and to recognize future areas that needed revisiting. For example, following the introductory session, we used a Nominal Group Technique (NGT) to confirm our target analysis and ensure the workshop focused on areas of need. Participants were asked to brainstorm specific areas they wanted the workshop to cover and through a ranking process common they prioritized 29 items. We reviewed 
our program to ensure the areas of highest priority were included. The first eight priority areas are shown in Table 2.

Take in Table 2 about here

An outcome of this activity was that a shared understanding of all participants' work and their reasons for attending the workshop developed across the group. We became more interactive collectively, and began discussing each other's issues and sharing common experiences related to the topics. We understood that both issues and prioritization could change as the program provided opportunities throughout the three-day workshop for participants to give us reflective feedback as a means of checking for their understanding. For example, positive feedback gave us confidence that participants valued the workshop. A typical response after the first day was:

The day was all about empowering. I have realized that change must start inside-out.

However, the following comment echoed a concern we had about the sequence of the program:

It was a good experience. I come from a quantitative background so today helped me to understand the qualitative paradigm better. The frustration (not serious!) so far: I wanted to know more about $A R / A L$ today already - the methods, report writing etc. I look forward to the next two days. Thank you so far.

Collecting, analysing and acting on participants' reflections resulted in on-the-run changes. In one instance we made a decision to re-sequence afternoon sessions as we felt participants needed more practical examples and tools for monitoring their projects. In another instance, we rescheduled the late-afternoon program to allow participants time and space to meet independently of the facilitators, or individually or in small groups with us, or to explore the local community.

One critical event calls for further description as it had a profound effect on the course of the workshop as well as the various stages in the reflection process. It acted as a stimulus for the transformation process and meta-reflection. It was a remark by a selffunded participant regarding the sensitivity of African participants to being objects of research. The participant observed that in his view the presenters' data collection process (part of action research) exemplified Western colonization of Africa, a topical issue as discussed by Kolawole (2005), Ramose (2005), Vambe (2005) and Meseleku (2004), among others. The observation raised divided responses, and strong emotions emerged in the ensuing discussions. Some of the issues raised related to the context under discussion in the workshop, but many were embedded in the historical context of the setting. As Waghid (2005) astutely observes, education cannot be understood in isolation from immense cultural (regional, historical and temporal) change. Reactions ranged across aggression, defensiveness and compliance. This diversion needed to be resolved in a way that restored all workshop participants' faith in the Action Learning and Action Research (ALAR) process and the functioning of the workshop. This required additional time and skills and thus impacted on the 
dynamics and evaluation of the workshop. It also influenced the learning of all involved, especially, ourselves as workshop facilitators.

At the end of the program, we invited participants to complete a summative evaluation which became the basis for our third cycle of reflections. These data provided valuable insights about our work in the design and implementation of the seminar workshop. We referred to this many times throughout our reflections.

\section{Summative Evaluation}

Assessment at the level of participant satisfaction is classified by Quiňones and Ehrenstein (1997) as the first level of evaluation and was conducted by means of a post-seminar summative questionnaire. The 21 participants were asked to rate the seminar in terms of categories on a scale of one to five $(1=$ very poor and $5=$ excellent). Mean scores were then calculated for each category for the group (see Table 3). Open-ended questions were also included in the questionnaire and these related to aspects that they felt could be emphasized more, emphasized less, added or left out. In spite of limitations of assessments conducted directly after interventions, since they have been noted to have a 'feel good' element (Knowles 1984), they nevertheless provide feedback on various specific aspects.

Take in Table 3 about here

Categories reflecting most positive responses (4.4 rating) were the capability of the facilitator as exemplified in this response:

- $\quad$ Workshop leaders were very warm, welcoming and professional.

All the presenters of the sessions were very good.

and the relevance of the content to the participants' personal situations. This relevance reflected the needs-based focus the workshop emphasised where participants identified areas of interest and project topics.

This positive response could be a result of the relevance of the workshop to participants' personal circumstances. The category where there was the least satisfaction was potential for implementation (3.5). This could be due to what some participants verbalized as the lack of funding to pursue projects with their new ideas and research abilities. Open-ended responses indicated that the aspects that participants would have liked added or emphasized related to the concepts of ALAR and planning, seminar presentation and group work activities. This is illustrated by one participant who said:

Present real examples of action research cases. Even if you present a set of very different examples in order to demonstrate that there is no template for action research, it would make a huge positive difference to my understanding if a few examples of projects were used.

In terms of the methods employed in the seminar, participants would have liked more opportunity for group work, sharing, interaction and critique. 
Examples of participants' statements:

...more group work and critiquing afterwards - it helps us grow.

Discuss problems we could have come across in our projects.

In general, the recommendations were for more of the same, and especially for more focus on the concepts of ALAR, a more participatory and interactive learning process, and more examples and discussion of projects. Discussion of participants' projects and application of the concepts of project planning, problem solving, management and monitoring could have been directed towards integration of learning from the workshop. Some recommended more time for interaction, sharing and group participation and some recommended extending the seminars for more than three days. This reflected the funding constraints and time limits of an ambitious three day workshop. These responses were food for thought and we spent the next cycle reflecting on these data.

\section{Post-Action Reflection: The Revisiting Phase of the Process (Cycle 3)}

In reporting the evaluation data and analysis in the previous section, we have remained true to the raw data and described how participants judged the worth of the workshop in terms of their experience and learning. The Australian team members met at the conclusion of the workshop to review all data collected during and at the end of the program, and to reflect on the effectiveness of the seminar. This was the first stage of our cycle 3 reflections.

\section{Cycle 3: Meeting 1 in Africa: Initial Reflections, Three Days Post-Seminar}

A need to gather our thoughts and to organize the data provided a strong procedural focus for our first meeting. Surrounded by laptops, notes, photographs and the sea of our ideas, we reviewed the workshop program, especially to consider the requirements upon us to fulfil our obligations to participants, the funding body and our institution. With our grant application and other formal documents in hand, this discussion was framed by questions such as: What worked and what did not? For whom? Why? Where to from here?

During this meeting we paused to read all the written feedback we had received, and shared our own perceptions of the seminar. The process remained a descriptive, oral discussion framed by an evaluative perspective. The talk revolved around language such as:

I thought the groups who had projects were very motivated and now have a plan of action to follow to implementation stage.

The problem with $X$ [a participant] was that she didn't have a project [on arrival at the seminar] to develop - this was a misunderstanding that caused difficulties when we workshopped action research within the context of the participants' projects. 
The data were generally very positive. However, three common needs were identified as mentioned above. First, there had been insufficient time; participants wanted more sessions than those we had been able to hold over the three days allocated. Second, there was a strong call for more examples of action research projects to deepen participants' understanding. Third, there was a need for even more interaction and for response to their specific projects. On first receiving participants' feedback we had looked at our own responsibility for any shortcomings and identified three issues: our insufficient knowledge before the seminar about participants' team projects, our lack of time, inability to obtain more funding, and the fact that some late-comers to the seminar (who had not received the necessary information) were ill prepared and had no project proposal or team.

At this meeting we were more preoccupied with the pragmatics of finalizing the project from an administrative point of view, rather than with developing a more reflective account of ourselves, our planning and its implementation. While this meeting was very important as a sift-and-sort exercise, from a reflective stance it was limited to interpreting literally the events that had taken place. It was very much grounded in our own personal experiences. We needed to distance ourselves from the program, and each other, in time and space, to reflect on the data critically in ways that might allow for alternative explanations about participants' responses - although we did not realize this at the time. Through email correspondence with our South African colleague we came to see this need. This insight became the focus of our next cycle of reflections.

\section{Cycle 3: Meeting 2 in Australia, Six Weeks Post-Seminar}

This second meeting was held in the form of a retreat so we could concentrate on issues raised during the previous meeting and on our reflections on the process so far. We also considered evaluation data and assessment from Ruth Albertyn, whose comments provided theorized reflection on the participants' evaluation of the seminar. She explained:

Transformation theory (Cranton 1994, 1996, Mezirow 1997) suggests that for sustained changed behaviour, the focus in an intervention should be on examining (and challenging) the frame of reference of individuals. In that way the change is not only adaptive (surface) learning, but also deep learning takes place. Maybe in the process of learning about ALAR in the case of this group, more time could have been focused on challenging basic assumptions of the participants many of whom were embedded traditionally in the positivist paradigm.

Comments in the evaluation indicate need for clear objectives, concrete examples, as well as trials to see how it could work in their environment. These suggest the need for empowerment as proposed by Spreitzer (1996) who found that security and clear goals and objectives are important in the process of empowerment. Their expressed need for more group interaction would have also built into the notion of empowerment as they would have had more chance to interactively solve their problems with less reliance on 
the outsider or expert (Albertyn 2005). The expressed need for continuation, on-going support and pressure to perform also is indicative of disempowerment in this regard as they have not as yet developed the skills of self-reliance regarding ALAR skills.

Albertyn's thoughts prompted further discussion of the participants' needs and how we could learn from their feedback. After much discussion, we decided to focus on our own reflection as the basis of an article that would develop and map the metaaction process. Each of us agreed to record individual reflections on our learning with the intention of critically re-considering the data in ways that would aim to transform our original interpretation of the evaluation, and transform our own learning. This new set of reflections, which would include those of our South African colleague, would become the basis for discussion at our next meeting.

\section{Cycle 3: Meeting 3 in Australia: Reflections on Reflections, Ten Weeks After the Seminar}

At this meeting our thinking developed towards a meta-level of reflection, that is, we were collectively reflecting on our personal idiosyncratic reflections. Until then we had interpreted the data within our personal frames of reference. Here with our individual written reflections collected in one document (13 pages) we could immerse ourselves in each other's interpretations of the participants' experiences. We agreed that this reading would focus on 'us' as the facilitators rather than the seminar participants. This unfolding moved us from an "I" and "you" perspective to a "we" view that we hoped would move us from the actual to the ideal (Zimmer 2001) Through our critical responses we shifted beyond personal response to more reflective ideas for future action. For example, Ortrun Zuber-Skerritt reflected:

I certainly have learnt that we have to make our values and ethical principles in participatory action research (PAR) clear to our associates in African and other developing countries. In essence these include planning, doing, evaluating, reflecting on, writing and publishing our research and development activities with and for them, not on them (like traditional research).

Although we were committed to the ideals of reflective practice and believed this process to be constructive appraisal, it was nevertheless confronting and at times discomforting. To illustrate we recount one event here. The reflection document contained several provocative statements that could be construed as finding excuses or explanations for what happened. For example, the following observation made by Margaret Fletcher was a genuine attempt to give honest feedback to her fellow facilitators.

At times I thought her presentation was a bit flat - and speaking from the lectern, managing the audio visual equipment might have created a barrier. It might have been more beneficial to use more personal stories and anecdotes to illustrate the content. 
We found that sometimes honest appraisal may be taken personally rather than as constructive feedback for further thought. This became a point of discussion for the group as we grappled with our own perceptions, biases and interpretations. We discovered learning from each other could be challenging and hurtful - a natural response to critical feedback. However this proved to be an enriching dialogue. We discussed our feelings openly as we engaged with critical feedback and grappled with our own insecurities.

Margaret Fletcher's record of her thinking during this meeting illustrates how the process of engaging with other perspectives transforms one's own view of events.

During the reading I looked for supporting evidence that would validate our reflections. I then looked for alternative explanations that might account for my and my colleagues' thinking, interpretations and perspectives. I tried to identify what I thought might be our own personal subjectivities and biases that influenced our view of the seminar and the events that took place. Through this process I identified particular things that warranted further explanation. I formulated questions that challenged the initial first draft reflections that documented our first order understandings of:

- the effectiveness of our practices and our work as facilitators,

- the needs of the participants,

- the seminar events, and

- the achieved outcomes.

A verbatim excerpt from the transcript of Margaret Fletcher's questions follows:

- We all learned a lot about the complexities associated with bringing a diverse group together that represented a range of experience and needs. I wonder:

- Was this really a collaborative, participatory process?

- Did we present as the experts?

- Did we apply a top-down approach - a transmission model to delivering the content?

- Did the input need to be top-down?

- What are the assumptions we were working under that shaped our actions/ presentations?

- Was the action research process evident in the seminar? Did it need to be?

As a group we used these questions to review critically our reflections and what we had 'taken for granted' in a sometimes superficial interpretation of our experiences. This was not an easy process as we would often fall into the practice of selfjustification by highlighting the limits and constraints of working with a group of people over a short period of time and with limited funding. As experienced professionals ourselves, we found it confronting - and difficult -to identify how our own ignorance was at work throughout the process, while we worked with and facilitated a group of people from a cultural context and with life experiences and world views very different from our own. 
The challenge for us was to deal with and learn from the reality of the experience, and not to use this reality as a rationalizing and sole explanation. The questions stimulated much discussion and helped us move to another level of understanding which became the basis of our fourth meeting. We recognized that different perceptions transformed our view of ourselves. We recognised our vulnerabilities as researchers as we engaged in a dialectical process about the assumptions we were bringing to the seminar experience. We went back to our original reflections and the evaluation data and sought alternative explanations for our actions. Our concerns centred on the validity and reliability of the methods used in researching our collective practice. The nature and extent of this difference forced our level of inquiry, through shared critical selfreflection, into areas within the meta level of reflection/action/research that we may not have been forced into under other, more familiar, more comfortable circumstances.

\section{Cycle 3: Meeting 4 in Australia, Fourteen Weeks After the Seminar}

Almost one month had elapsed over the holiday period before we were able to organize our fourth meeting. During this time we communicated via email as we shared our own thinking further with each other. For example, while Judith had worked collaboratively with the Australian authors in local research projects this was her first trip to South Africa. Her reflections following the third meeting illustrate how she synthesized her thinking across meetings to arrive at new understandings about her experiences and own knowledge and purpose:

I am now questioning the set of personal beliefs that prompted me to suggest that the participants lacked passion for their projects. I don't think I have enough understanding of the African experience. We stayed in accommodation that was westernized and privileged so the trip helped me to understand the African experience in a superficial way. However, it has left me with a motivation to understand that experience perhaps by reading in the first instance.

Ruth Albertyn's view had also changed,

My reaction after reading Ortrun's reflection (during cycle 3) was a protective one and I found myself again wanting to give an attempted explanation of the African perspective so that she (and the other Australians) won't feel so bad about the fact that their intentions were queried. Being a peacemaker type personality, I am trying to protect but as an educator and researcher I should give up this desire for control (which it is) and let the process run its course. Then I realized that as educators and especially action researchers we are continually faced with ourselves and in the process of growth and transformation. The 'uncomfortable' learning experiences we should allow to unfold, as this is the key to deep learning.

Albertyn highlights the great teaching power of 'discomfort'. Importantly, here the 'uncomfortable learning experiences' operated on two levels. One was in the different (for team members) cultural context in South Africa. The other was in the different (for team members) emotional/discursive space of our meta-reflections, where we 
needed to thoughtfully critique each other's involvement irrespective of our experience and status in the field. This progressed through emails that tracked and expanded our thinking and feelings about the experience. For example, Bartlett drew on metaphors and reflected on the project in terms of 'dreams that gave birth to hazy plans' which became more enlightened as our thoughts of what constituted usefulness were applied through the action research cycle.

The nature of our email communications played an important role in providing a time and space that allowed our individual responses to develop in a more distanced and critically reflective manner. We had the permanency of the written text to revisit and ponder, to make connections that sent us back into the literature as we looked for explanations that would account for our changing perceptions and transformation of our understanding. The following response illustrates this intertextual process as Fletcher moved from Bartlett's metaphors to Albertyn's, Kearney's and ZuberSkerritt's reflections, and back to the literature on critical theory. It is here that knowledge is being transformed through interactions with several texts. This knowledge was personal but needed to be grounded in a theoretical framework as discussed below in the following email:

As I attempt to engage in the meta-reflection process, your metaphoric reflection stimulated a different response for me about how we are trying to critically abstract our experiences as action researchers within the SA [South Africa] experience. Your words connected to those of Ruth about 'protective'; 'the South African experience' 'control' and 'disempowering'. You have both managed to send me back to research theories and I have found a helpful article that explains in some way what we are all trying to achieve in this paper. The following quote from the paper helps me here:

'Critical theory, demanding what Gramsci describes as 'a critical perspective', involves the ability of its adherents to criticize the ideological frames that they use to make sense of the world' (Kincheloe and McLaren 2000: 288).

While face to face, synchronous dialogue was one useful trigger in producing knowledge, asynchronous email communication enabled a more thoughtful and measured process of reflection. It allowed time to think through our own personal interpretations and responses and to make sense of these in light of the written responses of our colleagues. But we felt a need to connect in real time on Skype with our South African colleague, Ruth, whose physical presence was missed in our meetings. An outcome of this meeting was a deepening, collective understanding of ourselves as learners. Our critical reflections had moved our thinking to a meta level beyond simple description of the events we experienced, and through listening and responding to 'others', our critical reflections had moved us towards a critical understanding of our selves.

As we came together across the Internet for what was to be our last meeting we felt a synergy in our thinking. We discussed Ortrun's drafts of the models (Figures1, 2 and 3) that would illustrate the meta-action research process in ways that might be meaningful to readers. When we spoke 'face to face' in our video conference with Ruth we all felt a connectedness through our shared experiences as reflective practitioners. We were indeed collaborators who had searched for understandings that 
resulted in new knowledge about ourselves as individuals, as a learning community and as action researchers.

Following this meeting, Ortrun documented the final stages of our collaboration in the following reflection:

Our fourth meeting and subsequent communication via e-mail represent our meta-reflections on the previous cycle and our decision to come to a closure soon. This means, we wanted to write an article in which we would demonstrate the processes we used to reflect on our professional practice (LDP), on our transformational learning from our collective and reflective practice, and on concept maps that might be useful to other professional practitioners.

\section{Pro-action reflection for Improved Practice and Model Building (Cycle 4)}

Pro-action reflection focuses on learning from and understanding of the action - in our case the leadership development program - to improve or change practice and future events. So far in this paper we have used text/language to communicate our processes of transformative learning. In this section we conceptualize and generalize these processes through three two-dimensional visual models: (1) the PIPP model of reflection on action, as previously explained in Figure 1; (2) the meta-action research model; and (3) a more detailed model showing the spiral of meta-action research cycles that lead to continuous lifelong learning.

\section{PIPP Model of Reflection on Action}

With reference to Figure 1, the reader is reminded here of the key concepts in more general terms.

Action refers to professional practice, in our case conducting the leadership development program that we designed, implemented, evaluated and reflected on.

Pre-action reflection refers to our deliberate, strategic plan for AusAID participants before the event, based on our previous experience, knowledge and understanding of the literature in the field (cycle 1).

In-action reflection refers to our rapid, direct recognition of a situation or incident and our instant, intuitive reactions and decision-making during the event (cycle 2).

Post-action reflection about and away from the action is reflection focused on critical incidents after the event (cycle 3). The main collaborative contacts occurred during our research retreat meetings in Africa immediately after the seminar when we sorted, analysed and interpreted the data; and some months later in our reflection meetings in Australia in six, ten and fourteen weeks after the seminar followed by subsequent communication by skype, e-mail and google docs, a collaborative writing tool. 
Pro-action reflection (cycle 4) means learning from, understanding, and conceptualizing the action for improving our own professional practice in the future and contributing to others' knowledge in the fields of leadership development, reflective practice, lifelong learning, action research and meta-action research.

\section{Meta-action Research Model}

Figure 2 on meta-action research shows the four cycles of action research in more detail.

Take in Figure 2

The four cycles are:

1. The event itself as action research (AR 1), i.e. the leadership development program;

2. Meta-AR 2: our initial reflections on the AR 1 process and results;

3. Meta-AR 3: our later meta-reflections on our meta-AR 2; and

4. Meta-AR 4: our conceptualization of the whole process (of AR 1, meta-AR 2 and 3) and possible future applications, model building, and writing this paper for publication;

and finally, pointing to the next cycle of meta-action research in the same or other projects/contexts as a new beginning based on our first spiral of meta-action research cycles.

\section{Model for Lifelong Learning Through Meta-Action Research}

Figure 3 is a more detailed illustration of the four kinds of action research in Figure 2 and how each builds on the other as a process to progress reflecting, thinking and theorizing to higher levels.

Take in Figure 3 about here

The first cycle of action research (AR1) refers to our event and professional practice in the LDP - or more generally to any professional practice, where we plan the intervention, implement it, observe and evaluate it and reflect on the results of the evaluation, followed by meta-reflection on the whole process of the action research and elevating our thinking and feeling (head and heart, in both the cognitive and affective realms) to a meta-action research level in the second cycle.

The second cycle of meta-action research (AR2) represents our first team meeting immediately after the event in Africa when we (1) planned our activities for the research retreat in Africa; and (2) acted by sorting, analysing and making sense of the information we had collected in the first cycle of action research; (3) observed our reactions individually, of each other and as a team; and (4) reflected on the whole process of the three previous stages in this cycle. We found this process so constructive and enjoyable that we decided to continue our reflective practice and to meet as a team in Brisbane, but to include Ruth in South Africa as much as possible in our deliberations, as our collaborator and co-author. 
The third cycle of meta-action research (AR3) represents our reflections on our learning. Again we (1) planned the activities, (2) read each other's draft reflections including Ruth's writing by e-mail, and discussed them; (3) observed our behaviour that was initially rather defensive, finding excuses or explanations for what happened in this and previous cycles, and gradually learning to be more open to self-criticism and inviting criticism from others; (4) reflected on the effects of this critical approach to meta-reflection and experienced personal transformational change (in ourselves and in one another) that deeply affected our learning and future professional practice. We felt we were almost ready for conceptualizing and theorizing about reflection, metareflection, action research and meta-action research in the next cycle of meta-action research.

The fourth cycle of meta-action research (AR4) continued in subsequent communications via the Internet. It represents our meta-reflections on the previous cycle and our decision to come to a closure soon. This means, we wanted to write an article in which we would demonstrate the processes we used to reflect on our professional practice (LDP), on our transformational learning from our collective and reflective practice, and on concept maps that might be useful to other professional practitioners.

We believe that the three models presented here provide a basis for discussing the implications of meta-action research for improving leadership development programs (and other professional development programs) and for possible wider applications yet to be identified. In the next and final section, our concluding comments will highlight the value of these process models in contributing new understandings that may lead to new and better practices for lifelong learning.

\section{Conclusions}

In systemic practice, it is important to recognize that knowledge from hindsight needs first to be made explicit through reflection, then to be nurtured, and finally to be acted and re-acted upon within a collaborative, critical framework. This paper is the result of knowledge being constructed through an iterative process where our progressive experiences throughout each meeting were reframed through different lenses of interpretation. We believe we would never have transformed our understandings at a meta-level without the interactions that stimulated our reflections to move beyond the descriptive to embrace the critical. The process was enriched through face-to-face and online communications that created different spaces for new experiences and that stimulated different ways of thinking. Face-to-face dialogue was confronting and reactive as we learnt to trust one another and ourselves to share our thinking. Online dialogue provided time to explore each other's reflections, to digest each other's interpretations and to see the connections and synthesize our shared experience through a more thoughtful response to each other's writing.

The collective nature of the exercise assumed a life of its own as we opened our hearts as well as our minds to each other's perspectives and attempted to view our work through the experiences of 'others'. It was only through embracing the perspective of others that we could better recognize and appreciate our own assumptions and biases. Transformative learning is an empathetic process that is uncomfortable but enriching and lifelong. We believe that reflecting on actual experiences through the processes 
described here has moved us as practitioners towards an "ideal". Our efforts align with Zimmer's (2001) suggestion that practice is likely to be improved through practising what we preach. We have learnt a great deal- and will continue to do so in our current and future action research. The exhilaration of 'becoming' through evolving as a lifelong learner and action researcher is truly rewarding. We believe the process we have described in this paper using reflection on action and meta-action research is one way to achieve this.

\section{References}

Albertyn RM (2005) Increased accountability through monitoring empowerment programmes. Journal of Family Ecology and Consumer Sciences 33:31-36

Altrichter H, Feldman A, Posch P, Somekh, B (2008) Teachers investigate their work: an introduction to action research across the professions, 2nd edn. Routledge, London

Bartlett BJ (2003) Valuing the situation: a referential outcome for top-level structurers. In: Bartlett BJ, Bryer F, Roebuck D (eds) Reimagining practice: researching change. Proceedings of the 1st International Conference on Cognition, Language and Special Education. Brisbane, School of Cognition, Language and Special Education, Griffith University, Brisbane, pp 16-37

Bartlett BJ, Elliott SN (2008) The contributions of educational psychology to school psychology. In: Gutkin TB, Reynolds CR (eds) The handbook of school psychology, $6^{\text {th }}$ edn. Lawrence Erlbaum and Associates, Mahwah New Jersey, pp 65-83

Berg AM, Elkland O (eds) (2008) Action Research and Organisation Theory. Peter Lang Publishing Group, Frankfurt

Boud D, Keogh R, Walker D (1985) Promoting reflection in learning: a model. In: Boud D, Keogh R, Walker D (eds) Reflection: turning experience into learning. Kogan-Page, London, pp 18-40

Churchman C W 1979) The Systems Approach and Its Enemies, Basic Books New York

Cranton P (1994) Understanding and promoting transformative learning. Jossey-Bass, San Francisco

Cranton P (1996) Types of group learning. New Directions for Adult and Continuing Education 71: 25-32

Denzin, N (2009) Qualitative inquiry under fire. Left Coast Press, Walnut Creek, CA

Dick B (2004) Action research literature: themes and trends. Action Research 2(4): 425-444

Dick B (2006) Action research literature 2004-2006: themes and trends. Action Research 4(4): 439-458

Dick B (in press) Action research literature 2006-2008: themes and trends. Action Research, DOI: $10.1177 / 1476750309350701$

Fletcher MA (2005) Action learning/action research: a teacher-centered approach for self-improving schools. Literacy Learning: Middle Years 13(2):16-24

Fletcher M, Zuber-Skerritt O (2008) Professional development through action research: Case studies in South African higher education. Systemic Practice and Action Research 21:73-96

Flood RL (2001) The relationship of 'systems thinking' to action research. In: Reason P, Bradbury $\mathrm{H}$ (eds) Handbook of action research: participatory action research and inquiry. Sage, London, pp 133-144 
Gray E (ed) (2009) Doing research in the real world. Sage, London

Greenwood D, Levin M (2007) Introduction to action research: social research for social change, $2^{\text {nd }}$ ed. Sage, Thousand Oakes, CA

Guile D, Griffiths T (2001) Learning through work experience. Journal of Education and Work 14(1):114-131

Gustafson K, Bennett W (1999) Issues and difficulties in promoting learner reflection: results from a three-year study

http://itcoeugaedu/ kgustafs/document/promotinghtml

Hatton N, Smith D (1995) Reflection in teacher education: towards definition and implementation. The University of Sydney School of Teaching and Curriculum Studies, Sydney http://www2edfacusydeduau/LocalResource/Study1/hattonarthtml

Jarvis P (1995) Adult and Continuing Education. Routledge, London

Joseph N (2003) Metacognition in the classroom. Pedagog 3(2):109-114

Kemmis S (2009) Action research as a practice-based practice. Educational Action Research 17(3):463-474

Kemmis S, Mctaggart R (1988) The action research planner, third substantially revised edition. University Press Victoria: Deakin

Kemmis S, Mctaggart R (2010) The action research planner, fourth substantially revised edition. University Press Victoria: Deakin

Kincheloe JL, McLaren P (2000) Rethinking critical theory and qualitative research In: Denzin NK, Lincoln YS (eds) Handbook of qualitative research, 2nd edn. Sage, Thousand Oaks, CA, pp 279-313

Knowles M (1984) Andragogy in practice. Jossey-Bass Publishers, California

Kolawole OD (2005) Mainstreaming local people's knowledge and implications for higher education. South African Journal of Higher Education 19 1427-1443

Lewin K (1948) Resolving social conflict: selected papers on group dynamics. Harper and Brothers, New York

Lewin K (ed) (1952) Selected theoretical papers. Tavistock Publications, London

Meseleku T (2004) African scholarship: some challenges facing intellectuals in South African higher education institutions. Ingede: Journal of African Scholarship 1(2):1-3

Louw I, Zuber-Skerritt O (2009) Reflecting on a leadership development program: A case study in South African higher education. Perspectives in Education 27(3):237-246

Mcintire A (2008) Participatory Action Research. Sage, London

Mcniff J, Whitehead J (2009) Doing and writing action research. Sage, London

Mezirow J (1978) Perspective transformation. Adult Education Quarterly 28(2):100110

Mezirow J (1991) Transformative dimensions of adult learning. Jossey-Bass Publishers, San Francisco

Mezirow J (1997) Transformative learning: theory to practice. New Direction for Adult and Continuing Education 74: 5-12

NRC - National Research Council (1999) Being fluent with information technology. National Academies Press, Washington DC

NRC - National Research Council (2005) How students learn: history math and science in the classroom. National Academies Press, Washington, DC

Ottmann, G, Laragy C, Damonze D (2009) Consumer Participation in Designing Community Based Consumer-Directed Disability Care: Lessons from a Participatory Action Research-Inspired Project. Systemic Practice and Action Research 22:31-44 
Procee H (2006) Reflection in education: a Kantian epistemology. Education Theory 56(3): 237-253

Quiňones MA, Ehrenstein A (1997) Training for a Rapidly Changing Workplace. American Psychological Association, Washington

Ramose M (2005) The African university in the twenty first century. South African Journal of Higher Education 19: 1187-1188

Reason P, Bradbury H (eds) (2001) Handbook of action research: participatory inquiry and practice. Sage, London

Reason P ,Bradbury H (eds) (2006) Handbook of action research: concise paperback edition. Sage, London

Reason P, Bradbury H (eds) (2008) The Sage handbook of action research: participative inquiry and practice. Sage, London

Reynolds M 1998 "Unfolding" Natural Resource-Use Information Systems: Fieldwork in Botswana Systemic Practice and Action Research 11(2): 127-152

Reynolds M (2006) Evaluation based on critical systems heuristics. In: Williams, B. and Imam, I. (eds) Using Systems Concepts in Evaluation: An Expert Anthology. Point Reyes CA, USA: EdgePress, pp. 101-122.

Schön D A (1983) The reflective practitioner: how professionals think in action. Temple Smith, London

Schön D A (1987) Educating the reflective practitioner. Jossey-Bass, San Francisco

Somekh B (2006) Action research: a methodology for change and development. Open University Press, Maidenhead

Somekh B , Zeichner K (2009) Action research for educational reform: remodelling action research theories and practices in local contexts. Educational Action Research 17(1):5-21

Spreitzer GM (1996) Social structural characteristics of psychological empowerment. Academy of Management Journal 39(2): 483-504

Stringer ET (2007) Action Research, $3^{\text {rd }}$ edn. Sage Publications, Thousand Oaks, CA

Trevitt C (2005) Universities learning to learn? Inventing flexible (e) learning through first- and second-order action research. Educational Action Research 13(1):57-83

Vambe MT (2005) Opening and transforming South African education. Open Learning 20(3):285-293

Waghid Y (2005) On the possibility of an African university: towards a scholarship of criticism deliberation and responsibility. South African Journal of Higher Education 19:1306-1314

Zemblyas M (2006) Work-based learning power and subjectivity: creating space for a Foucauldian research ethic. Journal of Education and Work 19(3):291-303

Zimmer B 2001 Practicing What We Teach in Teaching Systems Practice: The Action-Learning Cycle Systemic Practice and Action Research 14, 697-713

Zuber-Skerritt O (ed) (1991) Action research for change and development. Gower Aldershot, UK

Zuber-Skerritt O (1992) Action research in higher education: examples and reflections. Kogan Page, London

Zuber-Skerritt O (ed) (1996) New directions in action research. Falmer Press, London

Zuber-Skerritt O (2007a) Leadership development in South African higher education: the heart of the matter. South African Journal of Higher Education 21(7): 982-1003

Zuber-Skerritt O (2007b) Action research and higher education in South Africa: personal experiences and reflections. In: D Santos and M Todhunter (eds) 
Action research and education in contexts of poverty: a tribute to the life and work of Professor Orlando Fals Borda. Ediciones UNISALLE, Bogotá Colombia, pp 49-70

Zuber-Skerritt O (2009) Action learning and action research: songlines through interviews, Sense Publishers, Rotterdam, The Netherlands 
Table i: Target analysis results $(\mathrm{n}=18)$

\begin{tabular}{|l|l|l|l|l|l|}
\hline Identified topics of interest & $\begin{array}{l}\text { Very } \\
\text { high }\end{array}$ & High & Fair & Low & $\begin{array}{l}\text { Very } \\
\text { low }\end{array}$ \\
\hline $\begin{array}{l}\text { Action Learning (AL): Philosophy, } \\
\text { theory and practice }\end{array}$ & 14 & 2 & 2 & 0 & 0 \\
\hline $\begin{array}{l}\text { Action Research (AR): Theory and } \\
\text { praxis }\end{array}$ & 15 & 2 & 1 & 0 & 0 \\
\hline $\begin{array}{l}\text { Qualitative Research: Paradigm, } \\
\text { methodology, methods }\end{array}$ & 12 & 1 & 5 & 0 & 0 \\
\hline Evaluation of an ALAR project & 13 & 4 & 0 & 1 & 0 \\
\hline $\begin{array}{l}\text { Leadership: } \\
\text { Concept and characteristics }\end{array}$ & 3 & 7 & 6 & 2 & 0 \\
\hline $\begin{array}{l}\text { A comparison between leadership } \\
\text { and management }\end{array}$ & 1 & 6 & 6 & 4 & 1 \\
\hline Transformational leadership & 7 & 6 & 3 & 2 & 0 \\
\hline Strategic planning & 10 & 4 & 2 & 1 & 1 \\
\hline Empowerment & 4 & 8 & 4 & 2 & 0 \\
\hline Powerlessness & 5 & 2 & 8 & 1 & 2 \\
\hline Interventions for empowerment & 5 & 12 & 0 & 1 & 0 \\
\hline Other: & $\begin{array}{l}\text { Change management, conflict management } \\
\text { and financial management (mentioned by } 1\end{array}$ \\
respondent) & & & \\
\hline
\end{tabular}


Table ii: Participants' areas of interest prioritized by weighted frequencies determined through a nominal group technique

\begin{tabular}{|l|l|}
\hline Priority & Issues \\
\hline 1 & $\begin{array}{l}\text { How to mobilize and align people; how to determine participation; } \\
\text { maintaining momentum }\end{array}$ \\
\hline 2 & Defining the research project topic \\
\hline 3 & $\begin{array}{l}\text { Developing research methods and techniques; the use of qualitative } \\
\text { methods in action research (AR) }\end{array}$ \\
\hline 4 & $\begin{array}{l}\text { Developing management and leadership skills; recognizing our limitations; } \\
\text { exploring the differences between action learning and action research } \\
\text { (ALAR) }\end{array}$ \\
\hline 5 & $\begin{array}{l}\text { Working with illiteracy and co-engagement; working with semi-literate } \\
\text { people }\end{array}$ \\
\hline 6 & $\begin{array}{l}\text { Report and article writing; how to ensure attractiveness to publishers; how } \\
\text { to present data collection }\end{array}$ \\
\hline 7 & $\begin{array}{l}\text { Using ALAR in projects; how to contribute to theory through } \\
\text { ALAR; theories and ALAR model; how to execute AR }\end{array}$ \\
\hline 8 & Combining academic and practical knowledge \\
\hline
\end{tabular}


Table iii: Summative evaluation $(n=21)$

\begin{tabular}{|l|l|}
\hline Question category & Mean score \\
\hline General organization & 4.2 \\
Achievement of goals & 3.8 \\
Level of presentation & 4.0 \\
Capability of facilitator & 4.4 \\
Learning gain & 3.9 \\
Relevance to personal situation & 4.4 \\
Potential for project implementation & 3.5 \\
Overall evaluation & 4.0 \\
\hline Total categories & 4.0 \\
\hline
\end{tabular}




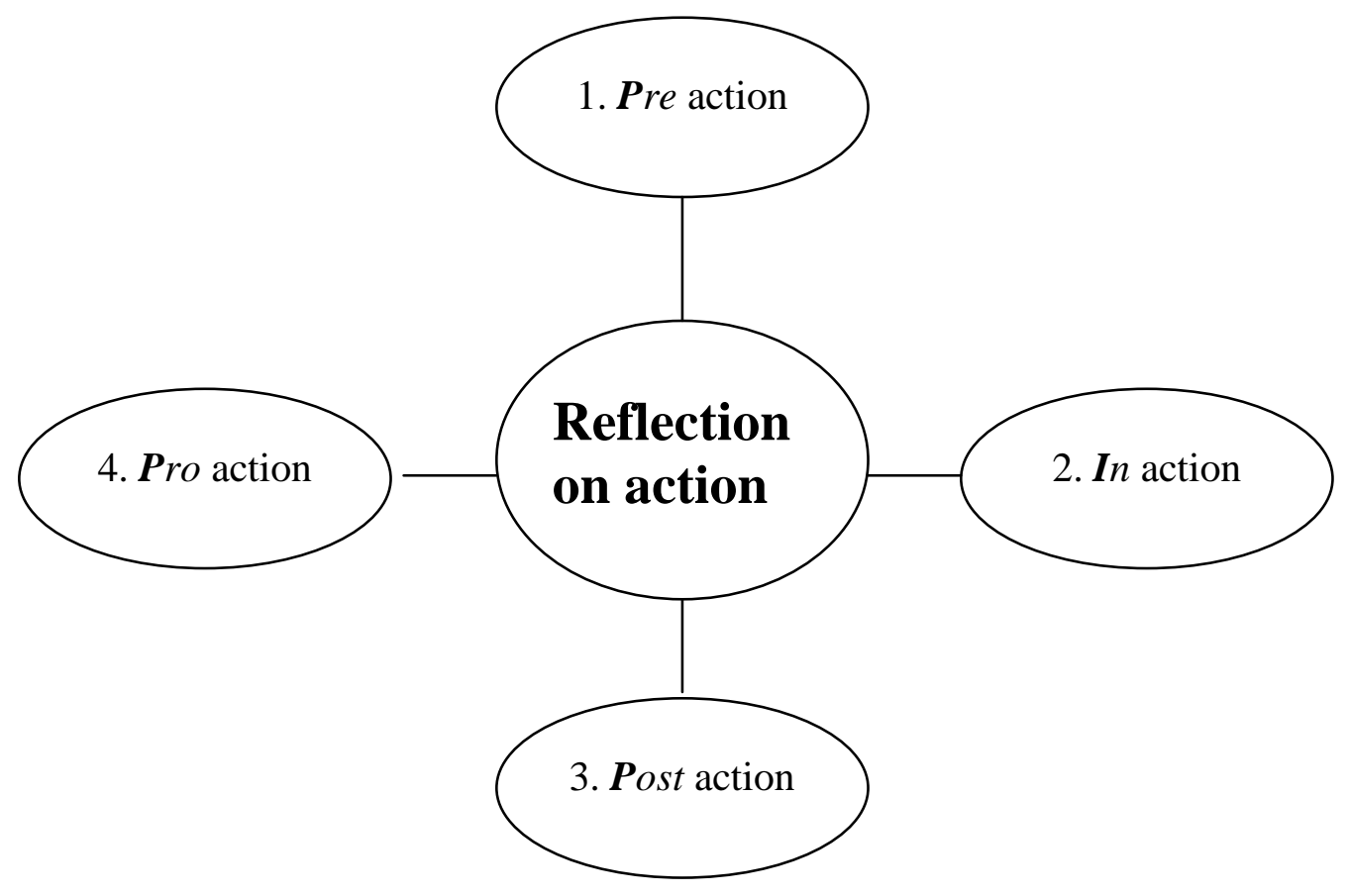

Figure 1: The PIPP model of reflection on action 


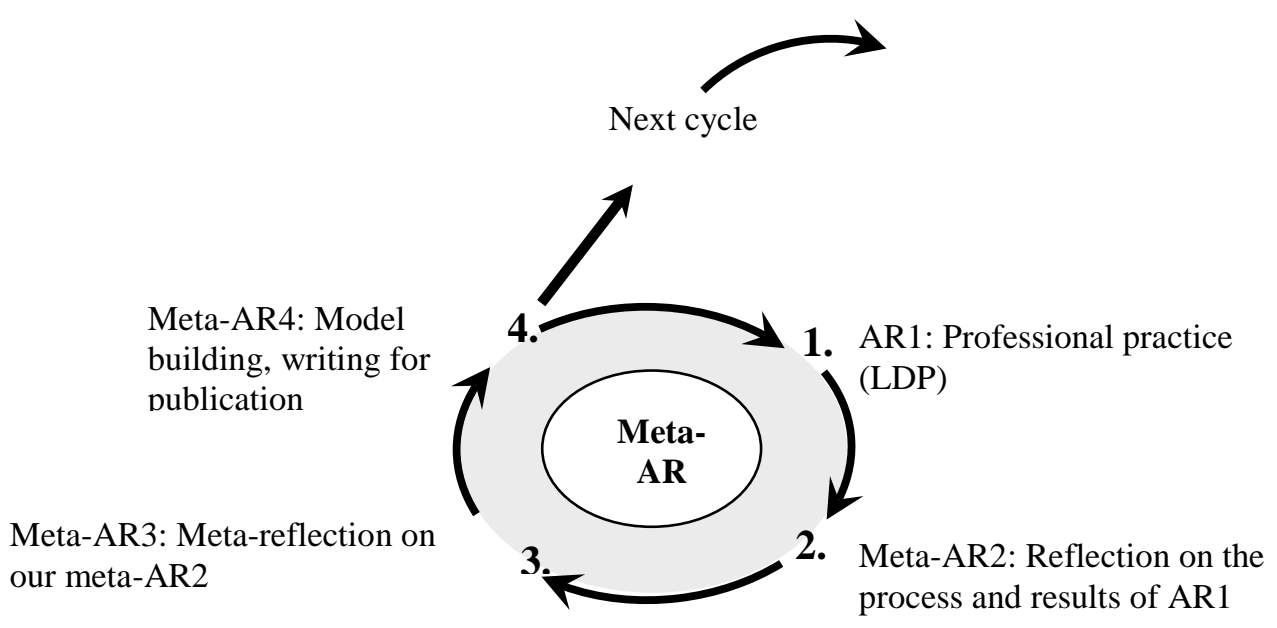

Figure 2: Meta-action research model 


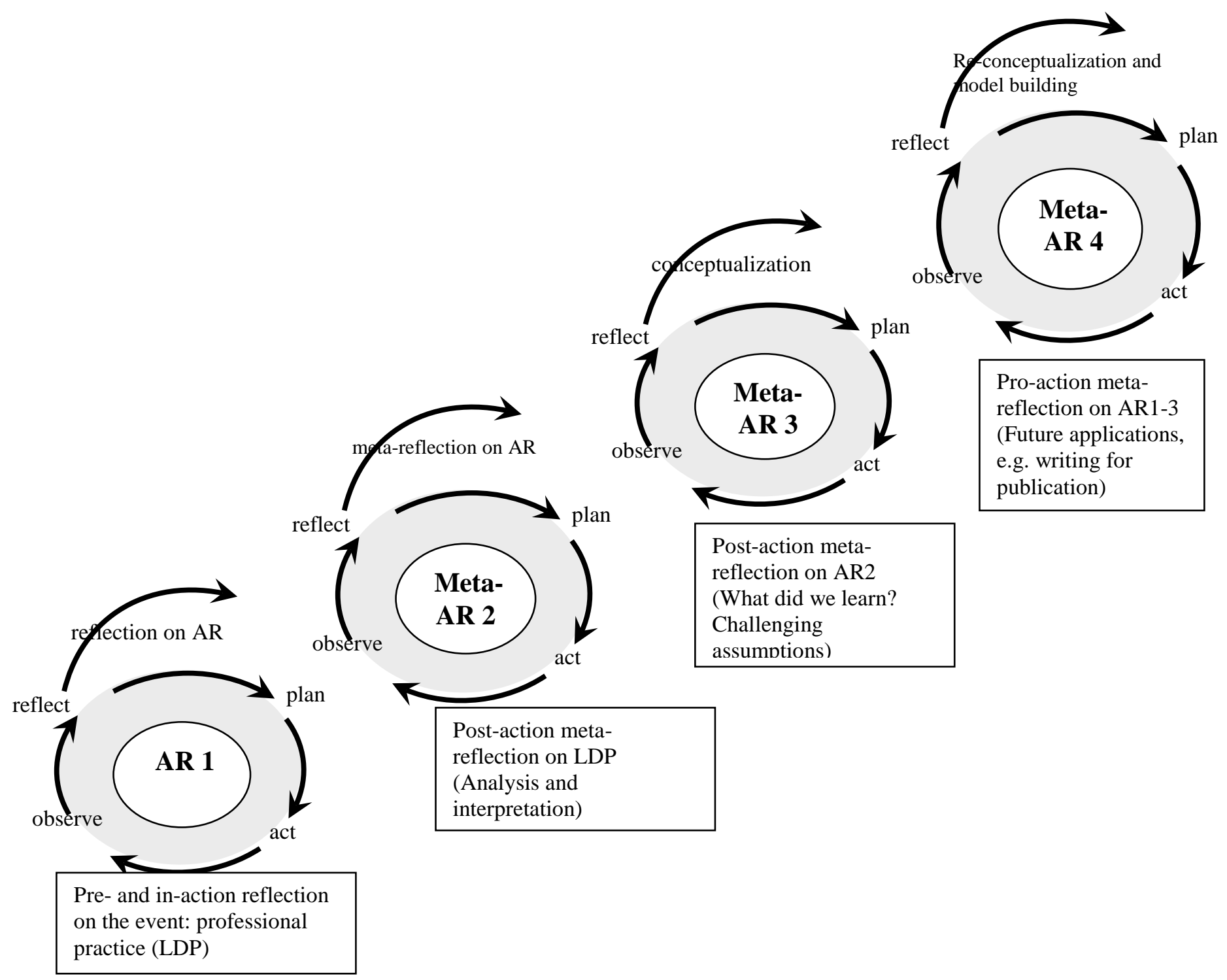

Figure 3: Model for lifelong learning through meta-action research 
Appendix 1: Leadership development program on poverty reduction through action research

\begin{tabular}{|l|l|}
\hline Topic & Issue, activity, approach, method \\
\hline $\begin{array}{l}\text { Action learning } \\
\text { (AL) }\end{array}$ & $\begin{array}{l}\text { Establishing theory: Beliefs, values, philosophical assumptions, } \\
\text { concepts, experiential learning theory; AL roles, processes, } \\
\text { strategies, projects, programs, applications, examples. Video with } \\
\text { Reg Revans. } \\
\text { Outcome: Final statements: Developing YOUR concept maps and } \\
\text { definition of AL. }\end{array}$ \\
\hline $\begin{array}{l}\text { Action research } \\
\text { (AR) }\end{array}$ & $\begin{array}{l}\text { Refining terminology: Comparisons between AL and AR; AR } \\
\text { concepts, models, practical applications, examples, problem areas, } \\
\text { and evaluation processes and procedures. }\end{array}$ \\
$\begin{array}{l}\text { Outcome: Final statements: Developing YOUR concept maps and } \\
\text { definition of AR. }\end{array}$ \\
$\begin{array}{l}\text { Qualitative } \\
\text { Paradigms, } \\
\text { methodology } \\
\text { methods }\end{array}$ & $\begin{array}{l}\text { Claiming a research position: Research paradigms, methodologies, } \\
\text { qualitative methods of research and evaluation; knowledge claims } \\
\text { and evidence, triangulation, participant validation, reflection journal. } \\
\text { Outcome: YOUR selection of appropriate methods and techniques } \\
\text { for your project. }\end{array}$ \\
\hline $\begin{array}{l}\text { Empowerment } \\
\text { leadership }\end{array}$ and & $\begin{array}{l}\text { Understanding, being aware or reminded of the essential } \\
\text { characteristics, values and strategies of being a leader and becoming } \\
\text { empowered. } \\
\text { Outcomes: YOUR vision of being a transformational leader; and } \\
\text { your concepts, principles and strategies of empowerment. }\end{array}$ \\
\hline $\begin{array}{l}\text { Project } \\
\text { (design, conduct and } \\
\text { evaluation) }\end{array}$ & $\begin{array}{l}\text { Designing a team AR project: Socratic approach to project design; } \\
\text { team vision building; stake holder analysis; SWOT analysis; model } \\
\text { of strategic planning; team project design using the AR spiral, } \\
\text { Figure Eight Model', and the 'Change Management Resources } \\
\text { Workbook'; checklist for evaluating project proposals. } \\
\text { Outcome: YOUR project vision and strategic plan. }\end{array}$ \\
\hline
\end{tabular}

